
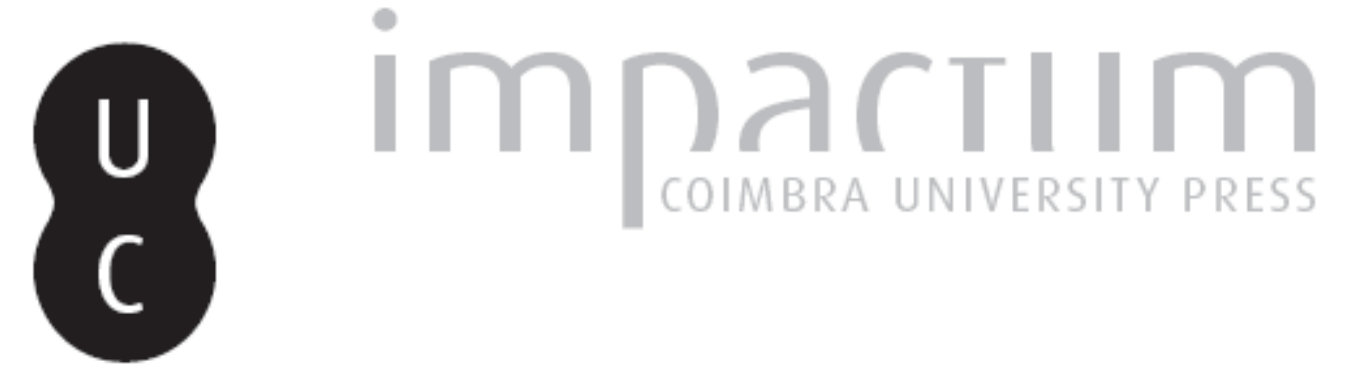

\title{
Body modification and paleopathological evidence in the iconography from the 'Philosophical Travel' to Brazilian Amazonia by Alexandre Rodrigues Ferreira (1783 - 1792)
}

$\begin{array}{ll}\text { Autor(es): } \quad \text { Martins, Maria do Rosário; Santos, Ana Luísa; Miranda, Maria Arminda; } & \text { Matos, Vítor }\end{array}$

Publicado por: CIAS - Centro de Investigação em Antropologia e Saúde

URL persistente:

URI:http://hdl.handle.net/10316.2/28696

DOI: $\quad$ DOI:http://dx.doi.org/10.14195/2182-7982_27_13

Accessed : $\quad$ 26-Apr-2023 10:10:14

A navegação consulta e descarregamento dos títulos inseridos nas Bibliotecas Digitais UC Digitalis, UC Pombalina e UC Impactum, pressupõem a aceitação plena e sem reservas dos Termos e Condições de Uso destas Bibliotecas Digitais, disponíveis em https://digitalis.uc.pt/pt-pt/termos.

Conforme exposto nos referidos Termos e Condições de Uso, o descarregamento de títulos de acesso restrito requer uma licença válida de autorização devendo o utilizador aceder ao(s) documento(s) a partir de um endereço de IP da instituição detentora da supramencionada licença.

Ao utilizador é apenas permitido o descarregamento para uso pessoal, pelo que o emprego do(s) título(s) descarregado(s) para outro fim, designadamente comercial, carece de autorização do respetivo autor ou editor da obra.

Na medida em que todas as obras da UC Digitalis se encontram protegidas pelo Código do Direito de Autor e Direitos Conexos e demais legislação aplicável, toda a cópia, parcial ou total, deste documento, nos casos em que é legalmente admitida, deverá conter ou fazer-se acompanhar por este aviso. 


\section{Antropologia Portuguesa}

Volume $26-27 \cdot 2009-2010$

Departamento de Antropologia | Universidade de Coimbra

DARWINISMO:

revisitações, propostas, problemas 


\title{
Body modification and paleopathological evidence in the iconography from the 'Philosophical Travel' to Brazilian Amazonia by Alexandre Rodrigues Ferreira $(1783-1792)^{1}$
}

\author{
Maria do Rosário Martins ${ }^{1,3}$, Ana Luísa Santos ${ }^{2,3}$, Maria Arminda \\ Miranda ${ }^{1,3}$, Vítor Matos ${ }^{3}$ \\ ${ }^{1}$ Museum of Anthropology, University of Coimbra, Portugal \\ 2 Department of Life Sciences, University of Coimbra, Portugal \\ ${ }^{3} \mathrm{CIAS}$ - Centro de Investigação em Antropologia e Saúde, University of Coimbra, Portugal \\ martinsr@antrop.uc.pt
}

\begin{abstract}
Iconographic representation of humans is an important source of evidence for paleopathologists. This is particularly so in acknowledging sociocultural practices in past and/or extinct populations. The aim of this work is to report images of body modifications and cases of paleopathological interest represented in the iconography recovered during the 'Philosophical Travel' to the Brazilian Amazonia, led by the naturalist Alexandre Rodrigues Ferreira (ARF) between 1783 and 1792 . Watercolors executed by the official expedition illustrators have been selected from the surviving archive. These portray individuals with their artefacts, clearly exhibiting cranial, facial and thoracic modifications, performed by groups such as the Tanarana, Cambeba, Jurupixuna, Mauá, Miranha, Caripúna and Uariquena. ARF also recorded the procedures and underlying cultural significance of these practices. The unequivocal pathological cases represented include a "male dwarf" [sic], and a Catauixi woman with dermatological lesions on her body. The author described with some details this skin condition and considered various possible diagnoses (e.g. vitiligo, scabies or leprosy). He also questioned whether these were hereditary or environmental in origin. This study considers the documentary evidence in the context of modern paleopathological inquiry, contributing to our understanding of cultural practices and diseases affecting the Amazonian inhabitants during the $18^{\text {th }}$ century.
\end{abstract}

Key words Artificial body modifications; dwarfism; skin diseases; differential diagnosis; biocultural approach; paleopathology.

Resumo As representações iconográficas de indivíduos são importantes fontes de evidências para os paleopatólogos, sendo particularmente relevantes no processo

${ }^{1}$ This paper is based on the presentation made at the $3^{\text {rd }}$ Paleopathology Association Meeting in South America, Necochea, Argentina, 14 ${ }^{\text {th }}-16^{\text {th }}$ October 2009. 
de reconhecimento de práticas socioculturais em populações do passado e/ou extintas. Pretende-se com este trabalho reportar os casos de modificações corporais e outros de interesse paleopatológico presentes na iconografia registada pelo naturalista Alexandre Rodrigues Ferreira (ARF), entre 1783 e 1792, no percurso da 'Viagem Philosophica' à Amazónia brasileira. Das remanescentes aguarelas, executadas pelos ilustradores oficiais da expedição, foram seleccionadas as que retratam modificações da cabeça, da face e do tórax, com os artefactos que lhes estavam associados, em indivíduos pertencentes aos grupos Tanarana, Cambeba, Jurupixuna, Mauá, Miranha, Caripúna e Uariquen. ARF também descreveu a forma com se processavam, bem como o significado cultural dessas práticas. Os inequívocos casos patológicos são os de um anão e de uma mulher Catauixi com lesões na pele. $\mathrm{O}$ autor descreve em detalhe esta última situação referindo possíveis diagnósticos (p. ex. vitiligo, sarna ou lepra) questionando igualmente a sua etiologia hereditária ou ambiental. O presente estudo, ao considerar as evidências documentais no contexto da investigação paleopatológica, contribui para o conhecimento das práticas culturais e das doenças que afectavam os habitantes da Amazónia no século XVIII.

Palavras-chave Modificações corporais artificiais; nanismo; doenças dermatológicas; diagnóstico diferencial; abordagem biocultural; paleopatologia.

\section{Introduction}

Paleopathologists examine both primary evidence (e.g. skeletons and mummies), and secondary sources such as contemporary documents (medical and historic records) and iconographic representations of artifacts and works of art (Lovell, 2000; Roberts and Manchester, 2005). Iconographic representation of individuals is an important source of evidence for paleopathological studies. This is particularly so in acknowledging sociocultural practices in present and/or extinct populations. However, as Roberts and Manchester (2005: 2) pointed out "when interpreting disease in the past from secondary sources care must be taken - opinions and preferences about what should be described and drawn will affect what is read and seen". Iconographic conventions may limit the realism of the representations and/or "bring to light ancient folk beliefs that influenced medical understanding" (Dasen, 1988: 254). 


\section{Objective}

The aims of this work are to report, and try to interpret cases of paleopathological interest and images of body modifications depicted in the watercolors executed by the official expedition illustrators during the 'Philosophical Travel' to the Brazilian Amazonia, led by the naturalist Alexandre Rodrigues Ferreira (ARF), between August 1783 and January 1792.

\section{Historical background}

After a first push, between the $15^{\text {th }}$ and the $17^{\text {th }}$ centuries, to learn about the coasts and travel routes on the oceans, the travellers of the 1700's started an era of discovery of the inland, and the knowledge of the inland was a goal to keep the conquest and to control the natural resources located in the territories (Raminelli, 2001). As examples from this period, we can mention David Livingstone, James Cook - who related the ingestion of fresh fruit with the prevention of scurvy - Alexander von Humboldt, Louis Antoine de Bougainville, among many others (Costa, 2001).

In the $18^{\text {th }}$ century, in Western society, the control over the environment, the ability to build and change raw-materials became important elements to assess and classify human communities (Raminelli, 2001). Through the Natural History, the value and importance of the territories was learnt and the naturalists acted simultaneously as scientific and imperial vectors, helping the expansion of European countries to other continents (Pratt, 1993 in Raminelli, 2001). This was the case of the 'Philosophical Travel' performed by Alexandre Rodrigues Ferreira.

Through the financial support of this scientific expedition, Portugal aimed the progress of science, a goal of the Illuminism, supported by the University of Coimbra and, more important, improving its administrative and economical power in colonial politics (Areia et al., 2005).

During the $18^{\text {th }}$ century, the cultural traces, such as physical modifications, clothing and artefacts, were used in the Western society as ways to identify and classify groups of people and as indicators of the "state of technological development" (Raminelli, 2001: 991). The artefacts and specimens gathered showed not only the potentiality of commercial and political expansion but represented also a material witness of the travelling. 


\section{Alexandre Rodrigues Ferreira and the 'Philosophical Travel' to Amazonia}

Alexandre Rodrigues Ferreira was born in Bahia, Brazil, in 1756 and died in Lisbon in 1815. He started the preparation to ecclesiastical life but latter, in 1770, he joined the University of Coimbra in the area of Law (Ferreira, 1971). In 1772, the reform of the University took place, under the government of the Prime Minister Marquês de Pombal, and the Faculty of Natural Philosophy was created. Two years later, ARF started his studies in this Faculty, receiving a degree in Natural Philosophy in 1779 (Lima, 1954).

In 1780 he became a correspondent member of the Royal Academy of Sciences (Real Academia das Ciências de Lisboa) and worked as a naturalist in the Royal Museum of Ajuda (Real Museu da Ajuda), in Lisbon, from 1778 to 1783 . At the age of 27, Ferreira was nominated by his former professor Domingos Vandelli, chief of the 'Philosophical Travel' to Brazil (Areia et al., 1991).

The Portuguese crown gave Ferreira the responsibility of a detailed research over nature, richness, products, season's definitions, rivers, lakes and fountains distribution, artefacts as well as the study of the three kingdoms of nature: animal, vegetal and mineral. The moral and physical knowledge of people were embedded with the productive activities, showing the interest of the traveller in checking the potentialities of agriculture and productive capacity of the populations (Raminelli, 2001).

The 'Philosophical Travel' to Amazonia covered approximately 39.372 Km (Lima, 1953; Simon, 1983) of the 'Capitanias' of Pará, Rio Negro, Mato Grosso and Cuiabá. Nine years later, in January 1792, he returned to Lisbon, where he occupied several official positions such as Director of the Royal Cabinet of Natural History and Botanics (Ferreira, 1971).

In many aspects, the 'Philosophical Travel' was a unique and major expedition:

- The magnitude of this mission can be acknowledged by the detail of the written records titled 'Memories, Diaries, Itineraries and Relations' (Memórias, Diários, Roteiros e Relações);

- Besides the naturalist, Alexandre Rodrigues Ferreira, the expedition included a botanical gardener, Agostinho do Cabo, and two drawers, Joaquim José Codina and José Joaquim Freire (Domingues, 1992; 
Raminelli, 2001). Cabo and Codina died during the journey (Areia et al., 1991; Domingues, 1992).

According to the recommendation for the expedition, a visual record by 'risk' and 'paint' (risco and pintura), would be produced when a written account was not sufficient to perfectly and clearly describe an object, a cultural practice or a person's body (Domingues, 1992). The drawing themes were ordered by the naturalist and produced in two steps: the drawers would start the watercolors in the field and later the works were finished at the Casa do Risco in the Royal Cabinet of Ajuda (Real Gabinete da Ajuda), in Lisbon (Domingues, 1992; Raminelli, 2001). Moreover, the watercolors were also duplicated, with slight differences namely in the sceneries. Domingues (1992) mentioned that in 1794 only 544, from a total of 1.015 watercolors, were duplicated. The surviving ones are nowadays housed at the National Library in Rio de Janeiro, Brazil, and at Bocage Museum/ National Museum of Natural History at the University of Lisbon, Portugal.

In agreement with the Prime Minister's, Marquês de Pombal, policy native people should be included in the colonization process as free individuals, performing agriculture, craft and commercial activities (Raminelli, 2001).

Ferreira, a George Buffon reader, tried to prove the thesis of the famous naturalist, and established that laziness and indolence were responsible for the delay of the Amazonia populations (Raminelli, 2001). However, in opposition to Buffon's thesis, Ferreira stated that natives "were not cold for love since not even hunger, plagues and wars weakened their sexual interest" (Raminelli, 2001: 989)2.

Inspired on the classifications made by Aristotle, Plinius and Linnaeus, Ferreira (Raminelli, 2001: 974) denominated the Amazonian natives as "terrestrial quadrupeds" (Class Mammals, Order Quadrupeds), variety Tapuio or Tapuia (Homo sapiens, Abá Mira - 1st var. americanus, tapuia). According to their physical appearance, Amerindians were classified in the following groups:

- 'Crafted monstrous' (monstruosos por artificio) - those who were born perfect but deformed themselves, according to bizarre habits;

2 "Não se mostravam frios para o amor, pois nem mesmo a fome, as pestes e guerras enfraqueciam o interesse sexual" (Raminelli, 2001: 989). 
- 'Natural monstrous' (monstruosos por natureza) - as the classification indicates, it refers to natives who were born with some distinguishing characteristics. For example, the Cauanaze resembled pygmies, "short stature, smaller that 5 hands" and the Ugina, the "tailed tapuias". To discuss this latter deformity, Ferreira gathered several testimonies among administrators and missionaries that had seen or heard about the "tailed indigenous". Despite his doubts, the naturalist adopted this typology and placed Ugina on the "natural monstrous" (Raminelli, 2001: 975-976). From this statement we realize that some of Ferreira's memories were based on alleged experiences of previous travellers and chronicles.

\section{The selected cases}

For this paper more than 300 watercolors were examined and organized in the following areas: Geography, Zoology, Botanic and Anthropology. The unequivocal pathological cases represented in the watercolors are presented here.

\section{Dwarfism}

According to Roberts and Manchester (2005: 2) "the curiosity factor in dwarfism" has "led to abundant representations of these conditions in art" in different cultures and chronologies.

The first depiction reported belongs to an 'indigenous male dwarf' (indio anão), called Marcelino (Figure 1), from the Tanarana ethnic group (Ferreira, 1971). The watercolors show an individual presenting a short stature with normally proportioned head and shortened upper and lower limbs. The thumbs and hallux look divergent from the other fingers and toes. Hallux divergence is relatively common in people that walk without shoes. However, it is impossible to know if the body proportions, as well as the divergences in the extremities, were actually present in the individual or if these resulted from the artist interpretation. No information concerning the age and the exact stature of Marcelino were registered by ARF. 

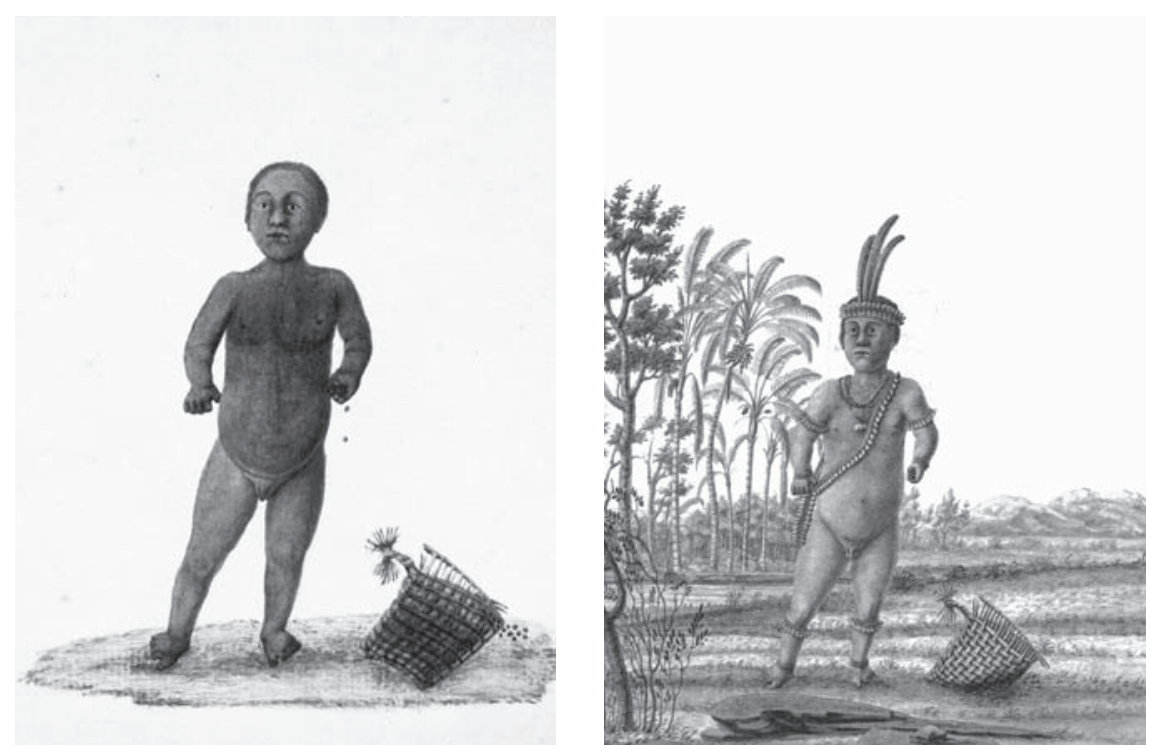

Figure 1. Watercolors representing Marcelino, a "male dwarf" from the Tanarana ethnic group who lived in Gurijúa, Brazil, 1783-1792. The image on the left (Areia et al., 1991: 82/ XXVII, housed at Museu Bocage, Lisboa) is in colors while the right is a black and white one (Ferreira, 1971: 123).

The term dwarfism is, nowadays, usually employed when an individual presents an abnormal short stature and, according to Waldron (2009: 195), it characterizes a person that is "below the $5^{\text {th }}$ percentile on a growth chart or 3 standard deviations or more from the mean height for age". This researcher also points out that it can result from several conditions although the most common ones are Turner's syndrome, inadequate nutrition, pituitary dwarfism, and achondroplasia.

Considering the differential diagnosis of Marcelino's dwarfism, the Turner's syndrome, that consist in a total or partial lack of one of the X chromosomes, is easily excluded since it only occurs in women and it is an extremely rare event (Waldron, 2009). From the drawing observation, there are no signs related to an inadequate nutrition and ARF described this individual using the term dwarf, what seems to exclude undernutrition as its cause. In the $18^{\text {th }}$ century the medical knowledge didn't allow the distinction between different etiologies of dwarfism, however, the visual identification of these cases was easily done. Thus, the most reliable diagnosis is pituitary dwarfism or achondroplasia. 
Pituitary dwarfism corresponds to a "loss of pituitary function during childhood" and it is characterized by proportioned body segments "as well as normally proportioned extremity lengths in relation to the trunk" (Aufderheide and Rodríguez-Martín, 1998: 328). Causes of pituitary dysfunction in childhood may have a neoplasm origin (Aufderheide and Rodríguez-Martín, 1998; Ortner, 2003) or, but far less common, a traumatic or congenital deformity or enzyme deficiencies, among others etiologies (Aufderheide and Rodríguez-Martín, 1998). These individuals are not intellectually handicapped (Aufderheide and Rodríguez-Martín, 1998). According to these authors, other characteristics described for this condition are the lack of appropriate development of the external genitals and the premature epiphyseal closure, both resulting from the decrease of gonadotropin production. Based on the watercolor it is impossible to evaluate the epyphiseal status of the long bones but the underdevelopment of sexual organs is visible. In fact, concerning this issue, the representation of Marcelino's genitals is one of the exceptions, since in the majority of the watercolors representing naked adult individuals this part of the body is frequently hidden by some artifact being carried by the person (e.g. Figure 2). This is not the case of Marcelino.

Thin skin and fine hair are also common in pituitary dwarfism (Aufderheide and Rodríguez-Martín, 1998) and the absence of growth hormone may provoke a delay in teeth eruption (Aufderheide and RodríguezMartín, 1998; Ortner, 2003). Again these features are difficult to access from the Marcelino's drawing.

In living people, pituitary dwarfism and cretinism can be distinguished respectively by the absence or presence of mental impairment, moreover, cretinism affects more the lower than the upper extremities (Aufderheide and Rodríguez-Martín, 1998), what is contrary to Marcelino's limb changes.

Another possible diagnosis is achondroplasia, a congenital and hereditary disease, also denominated short-limbed dwarfism. It is the most common form of non-lethal skeletal dysplasia (Aufderheide and RodríguezMartín, 1998; Ortner, 2003; Waldron, 2009). In these cases intelligence is normal (Ortner, 2003). Achondroplastic individuals appears to have disproportionately large head, "which is only partly an illusion due to its brachycephalic shape with frontal bossing and a shortened cranial base that leads to a depressed nasal bridge" (Aufderheide and Rodríguez-Martín, 1998: 358). In the extremities, the femurs are the most shortened bones, followed by the humerus, and by the lower legs and forearms (Aufderheide 
and Rodríguez-Martín, 1998). In the hands, the short and equal length of the fingers has been termed a 'trident' pattern (Ortner, 2003), and this feature seems to be present in Marcelino's representation.

The distinction between individuals affected by pituitary dwarfism or achondroplasia is considered relatively easy in clinical settings, however it must be emphasized that the paleopathological differential diagnosis of Marcelino's dwarfism, as represented in the iconographic record, is not straightforward. His body features are puzzling. Although limbs appearance is more likely attributable to achondroplasia, namely to the acromelic type - that consists in the shortening of the distal segments (Waldron, 2009) -, the normal shape of the head is more compatible with a case of pituitary dwarfism. This diagnosis is also compromised by the source of information, namely iconography. It is impossible to ascertain whether the picture is accurate concerning the body proportions of the living individual or if these were biased by the artist, which in this case may result in a misdiagnosis of the underlying pathological conditions. Independently of the limitations concerning the acknowledgment of the exact nosological entity responsible for the body changes presented by Marcelino, his depiction is very relevant since it shows that dwarfism was present in Amazonian people in $18^{\text {th }}$ century. The representation of dwarf individuals in iconography has been common since ancient times (Kozma, 2006). In different cultures dwarfs have been objects of curiosity and/or veneration (Haworth and Chudley, 2001; Waldron, 2009).

\section{Skin lesions}

A Catauixi woman presenting skin lesions on her body can be observed in Figure 2. Alexandre Rodrigues Ferreira noted this condition as common in this ethnic group and questioned whether these were hereditary or environmental in origin and considered this community as belonging to the group of "natural monstrous'. He considered various differential diagnoses, including vitiligo, scabies and leprosy. According to Millington and Levell (2007), vitiligo was also called white leprosy, and in Europe for many centuries it was confused with leprosy and other disorders presenting hypopigmentation. In 1765, the French physician Claude Nicolas le Cat published a book on skin color in which he "accurately detailed several cases of vitiligo that started in small areas and then progressed symmetrically over the hands and face" (Millington and Levell, 2007: 991). Only in the $19^{\text {th }}$ century, in Viena, Moriz Kaposi, 
described the histopathology of vitiligo, which is related to the destruction of melanocytes (Millington and Levell, 2007). This non-infectious disease was also distinguished from leprosy after the identification of the Mycobacterium leprae by Gerhard Hansen in 1873 (Feldman, 1965).

When considering the watercolor, Ferreira's differential diagnosis is understandable. However, according to current medical knowledge, the search for the aetiology of macular skin lesions is based upon specific clinical symptoms such as sensory loss (e.g. leprosy) or itching (e.g. onchocercosis) (Leiker, 1989). Relying exclusively on the topography of the skin lesions depicted in the watercolor and on specific signs, such as the dispigmentation of hair mentioned by Ferreira (1788), the tropical diseases ascribable to the differential diagnosis, such as treponematosis and fungal infections, can be excluded. Therefore, the most probable diagnosis is still vitiligo.

Figure 2. Colored watercolor showing the skin lesions on an "indigenous woman, from Catauixi group, inhabitants of River Purús that flow into the occidental margin of River Solimões". Drawing from Codina (Areia et al., 1991: 83/XXVIII, housed at Museu Bocage, Lisboa).

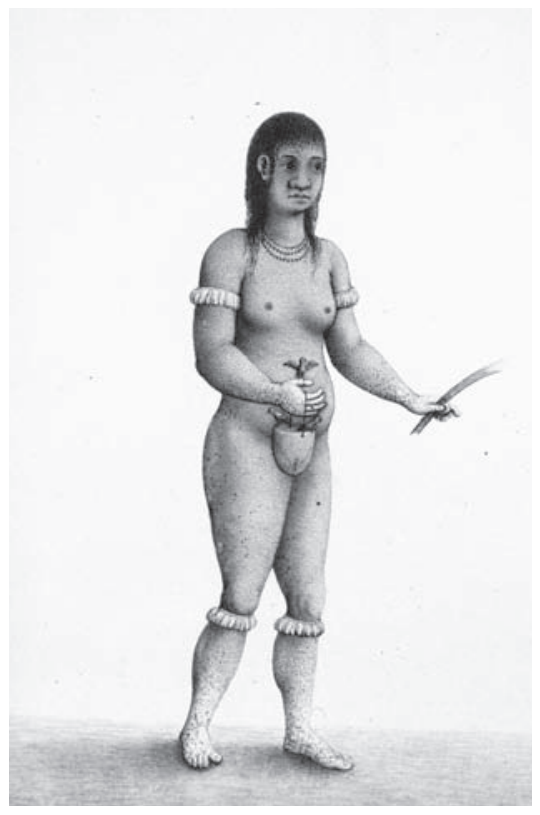

Despite the difficulty of interpreting iconographies, sometimes these represent unique sources of evidence from the past. Moreover, "[f]or many conditions $[\ldots]$ texts are missing and human remains are scanty" (Dasen, 1988: 253), as is the case of the Amazonian region where bones are rarely preserved due to soil and climatic characteristics. 


\section{Cranial, facial and thoracic modifications}

The artificial deformation of skulls was commonly performed by past human groups, especially from the Americas, as revealed by the osteoarchaeological record (Buikstra and Ubelaker, 1994). During the 'Philosophical Travel', ARF observed Amazonian people exhibiting cranial deformations and his descriptions were an important testimony to the history of this cultural practice in this region of the world.

The images from Figure 3 depicts a man belonging to the Cambeba group (Gentio Cambeba) or 'flat head' (cabeça-chata). The watercolor shows a man and a deforming device made of five cane stripes. Moreover, it is possible to observe the presence of an impression just above the supercilliary region left by the deforming device. In this watercolor the cranial modification seems to correspond to a "fronto-occipital" type, characterized by a vertical occipital and frontal flattening (Buikstra and Ubelaker, 1994: 160). According to ARF (2005e [1787]: 57) the resulting shape of the head may be flat, conic or quadrangular.
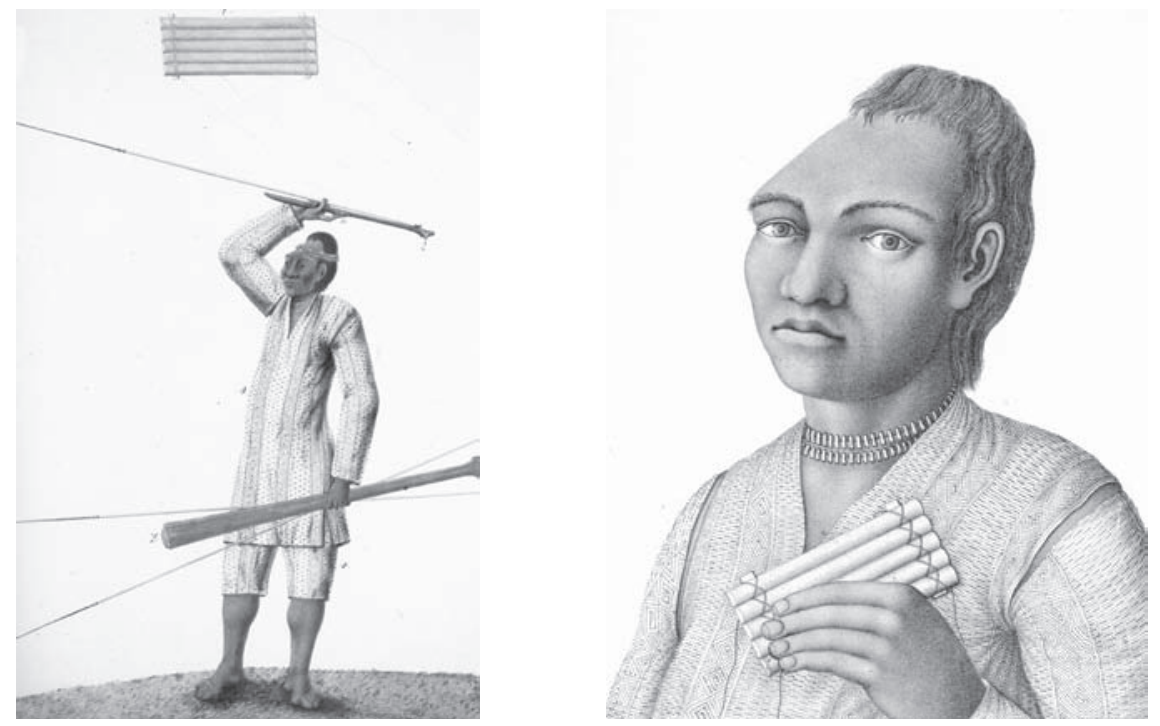

Figure 3. Watercolors representing a Cambeba man (Gentio Cambeba), who lived close to the River Yapurá, showing cranial modification and the deforming device used to perform this cultural practice, drawn in 1787 by Freire (left and right drawings respectively adapted from Areia et al., 1991: 79/ XXIV, housed at Museu Bocage, Lisboa, and Ferreira, 1971: 117, housed at National Library, Rio de Janeiro). 
Ferreira also recorded the procedures and underlying cultural significance of these practices: "all the populous nation has flattened heads, not by nature but artificially, because just after birth the head is compressed between two small wood pads, one over the forehead and the other in the back" (Ferreira, 2005b [1781]: 7) ${ }^{3}$. In order to prevent hurting of children's head, a small pillow was placed between the wood and the head. Otherwise, this would hurt the head because at that age the coronal bone and the two parietals, as all the other vault bones, are cartilaginous. The naturalist wrote that although this modification was more common in the past it was still practiced by the Cambeba in the $18^{\text {th }}$ century, who compressed with their hands the forehead of the children. The explanation for this practice argues that it represented a way of being recognized by the white people as a non cannibal group and therefore be free of slavery (Ferreira, 2005b [1781]) $)^{4}$. Moreover, ARF considered that the Cambeba were more civilized than other groups, also because of their whiter skin colour and their "elegant figure" (Raminelli, 2001: 977).

The artificial modification of the head of Cambeba people was reported before in the chronicles of Frei Cristóbal de Acuña in 1641 (1994) and by Netto, in 1882. Both authors mentioned that in Cambeba male and female children had their head compressed by a wooden device that in part became their cradle. In fact, the cranial modifications occurred all over the world being the most striking ones in Americas (Wells, 1971).

The Jurupixuna group used labrets in the lower lip as the one visible in the man from Figure 4. Ferreira used the expression "uma marca de $\operatorname{cogu}(i)$ lho" (Ferreira, 2005c [1787]: 31) to describe this labret, being unclear whether it is a batoque or a tembetá. According to Ribeiro (1988), these can be distinguished based on size and shape of the artificial opening of the lip, the batoque being made of wood and replaced during life allowing the increase of the labial perforation. Rodrigues-Carvalho and Souza (1998) also noted that tambetás are usually made of discoid or cylindrical polished stone.

3 "Toda a populosa nação tem as cabeças achatadas, não por natureza, mas sim por artifício, porque logo que nascem, lhas apertam entre duas tábuas, pondo-lhes uma sobre a testa, outra no cérebro e, como se criam metidas nesta emprensa, crescendo sempre para os lados, lhes ficam disformes" (Ferreira, 2005b [1781]: 7).

4 "Dizem que usam desta diferença tão especial para que, sendo conhecidos por ela entre todos os brancos, segurassem a sua liberdade na distinção notória de não comerem carne humana" (Ferreira, 2005b [1781]: 7). 
Ferreira (2005c [1787]) mentioned that due to the painful process associated with this practice the perforation of the lips of a child happened in the bush, far from their parents, preventing them from hearing the children crying ${ }^{5}$. Souza (2009) stated that this process starts with a very small hole that is progressively enlarged over the time.

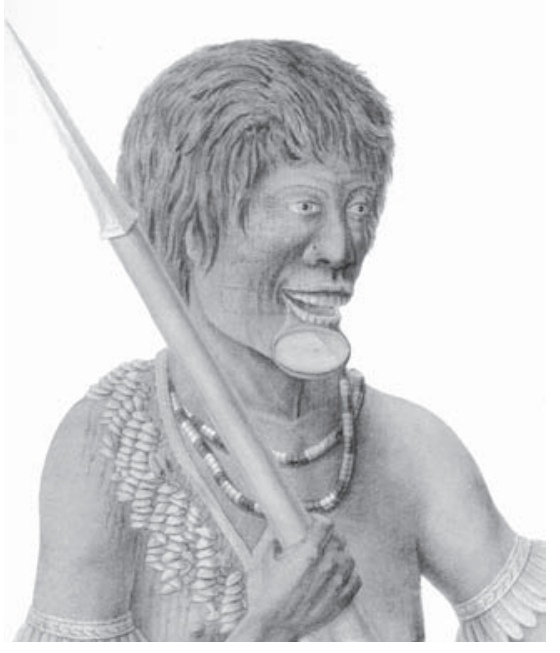

Figure 4. Indigenous man from the Jurupixuna group with a labret (Ferreira, 1971: 112).

It is known that labrets may provoke dental modifications, though inadvertently. The abrasion of teeth surface is caused by the friction with exogenous material. The dental lesions may vary depending on labrets dimension and the time and intensity of their use (Rodrigues-Carvalho and Souza, 1998). Dental wear, both in degree and pattern, has been shown to be of great value in the interpretation and understanding of prehistoric (and historic) human behavior (Larsen, 2002). However, as stated by TorresRouff (2003: 247) "[o]nly a small number of studies detailing the skeletal manifestations of labret use have been published".

Thoracic modifications were also observed and described by ARF. The Maua that lived in the margins of the Cumiary River could be distinguished from the other native groups because they used corsets, "like the ladies in Europe"

5 "Trazem outros [Jurupixuna] o beiço inferior furado e, no furo, introduzida a uma marca de cogu(i)lho [...] eles têm o cuidado de subtrairem os filhos e filhas da presença dos pais conduzindo-os para o mato retirado a onde não possam os pais ouvir o choro das crianças, quando se doem da mortificação que lhes causa a operação do referido ornato [...]" (Ferreira, 2005c [1787]: 31). 
as Ferreira (1974: 31) noted. According to his descriptions, this object was prepared with wood stripes that were fixed around the belly in direct contact with the skin (Figure 5). Consequently the false ribs were compressed in the region of the upper part of the kidneys while the true ribs became elevated towards the internal part, producing the effect of a gibbous thoracic cavity ${ }^{6}$.

Figure 5. Indigenous from the Mauá group using a corset (Ferreira, 1971: 111, housed at National Library, Rio de Janeiro).

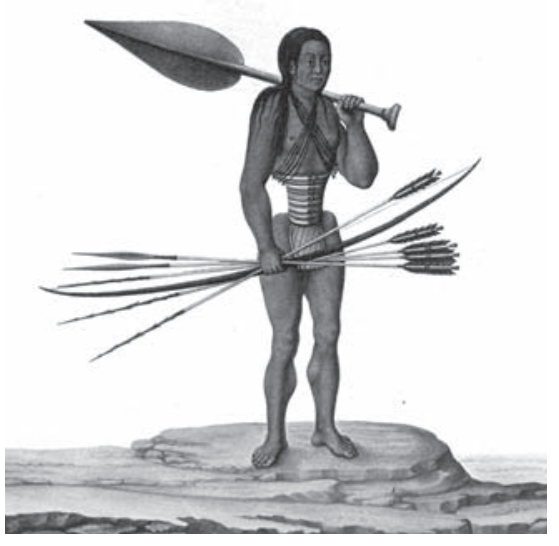

The detailed descriptions made by Ferreira concerning the body changes provoked by the prolonged use of corsets in Mauá people reveals that he was familiar with the anatomical consequences of this cultural practice. This is not surprising since the use of corsets was a very trendy habit amongst European women and the consequent body changes associated to this cultural practice was already a matter of scientific interest amongst the physicians from the $18^{\text {th }}$ century (Schwarz, 1979). Schnabel and Schnabel (1986: 184)

6 "Para fazerem o espartilho, preparam uma lâmina de madeira avermelhada do comprimento de uma até duas varas, em ordem a darem com ela três voltas em roda do ventre, como se fosse uma cinta, adelgaçando a lamina de sorte, que apenas lhe deixam a consistência, que têm os arcos das bocetas de faia. Dispõem à roda do ventre, com imediato contato sobre a pele uns grossos ponteiros perpendicularmente arranjados, os quais nesta qualidade de espartilhos ficam servindo de barbatanas, e sobre eles cingem a lâmina, atando-a por fora com as fitas que tiram da palmeira do tucum, pintadas de diferentes cores, e os nós que lhes dão pela frente do espartilho formam o trancelim que ataca. Donde resulta que, ficando por este modo comprimidas as costelas purias pela parte superior das cristas dos rins, se elevam as costelas verdadeiras para a parte interna, fazendo mais gilbosa a cavidade do tórax, como sucede aos corcovados e as cristas dos rins se elevam em forma de anquinhas e ficam mais vazadas, como se vê nos esqueletos das mulheres [...]" (Ferreira, 2005a [1787]: 33). 
noted that those who wore corsets were in risk of suffering from "deep excoriations that sometimes became infected and led to death", pulmonary hemorrhage, abortion, tuberculosis, scoliosis, among other physiological and pathological alterations on the internal organs (Fee et al., 2002).

Other body modifications were also represented in the watercolors from the 'Philosophical Travel', namely nasal and auricular perforations. Concerning the nasal modifications, ARF stated that in the case of the Miranha indigenous group these perforations (Figure $6 \mathrm{~A}$ ), done in both nostrils, were distinctive features of this group, especially during war, when macaws feathers were introduced in the nasal perforations (Ferreira, 2005d [1788]) ${ }^{7}$. In the Caripúna group, as depicted in the Figure $6 \mathrm{~B}$, a small stick pass through the nasal septum.
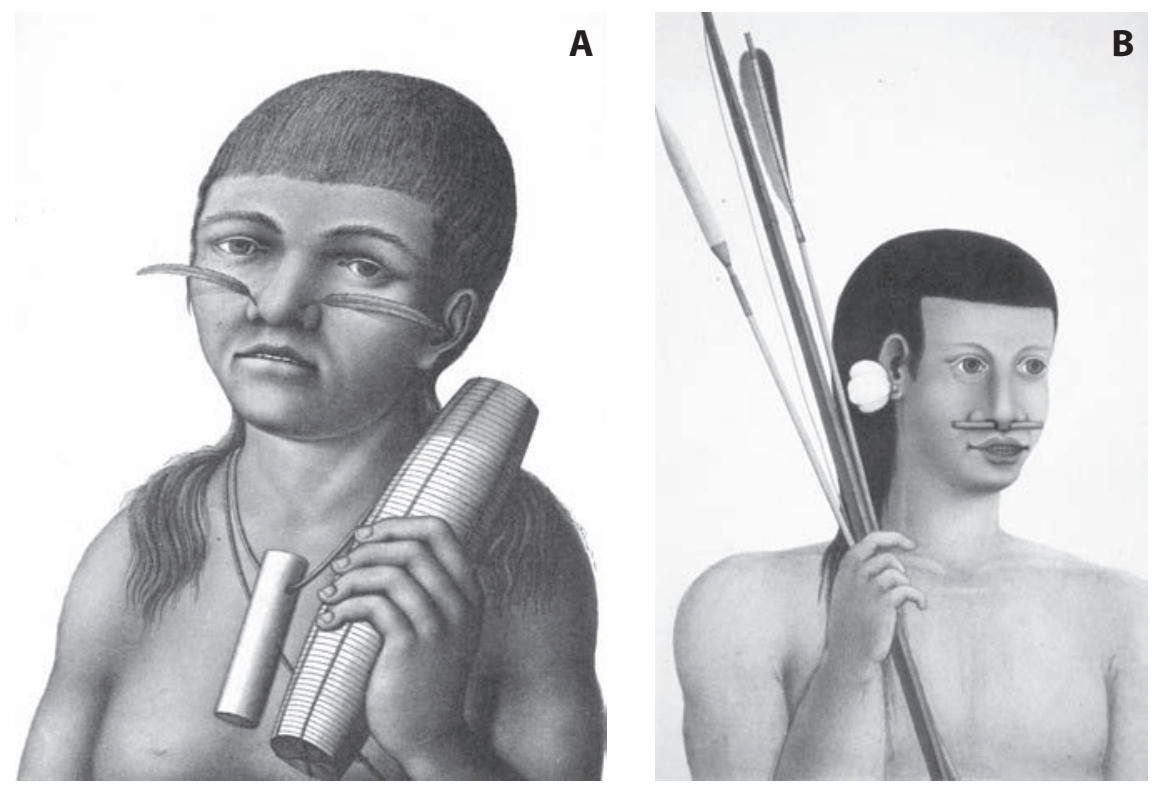

Figure 6. A. An indigenous from the Miranha group, inhabitant of northern margin of the River Solimões, with both nostrils perforated and filled with macaws feathers (Ferreira, 1971: CXIII, housed at National Library, Rio de Janeiro). B. The watercolor represents a man Caripúna, from the upper waterfalls of River Madeira, with an ornament perforating the nasal septum (Areia et al., 1991: 86/XXXI, housed at Museu Bocage, Lisboa).

7 "Distinguem-se dos outros gentios em serem claros, em terem ambas as ventas furadas e em trazerem introduzidas nos furos, pela ocasião da guerra principalmente, quando querem incutir maior terror, penas de cauda de arara, as quais, ficando em uma posição declinada representam umas bigodeiras" (Ferreira, 2005d [1788]: 35). 
The auricular modifications present in the Uariquena indigenous group (Figure 7) were classified by ARF as belonging to the category of "industrial signs and deformities" (Ferreira, 2005a [1787]: 47). The naturalist described these as consisting in large perforations located between the cartilage and the inferior extremity of both ear lobes. The perforations were progressively enlarged with sticks resulting in extremely big auricular holes where large objects could be inserted, for example, a bundle of straw, as exemplified in Figure 7. In extreme cases the auricular lobes were so modified that they could get in touch with the shoulders.

Figure 7. Watercolor depicting an indigenous from the Uariquena group, inhabitants of the waterfalls of Rio Ixié which flows into the River Negro, with bilateral auricular perforations filled with bundles of straw. Drawn by Freire in 1787 (Areia et al., 1991: 23/XXIII).

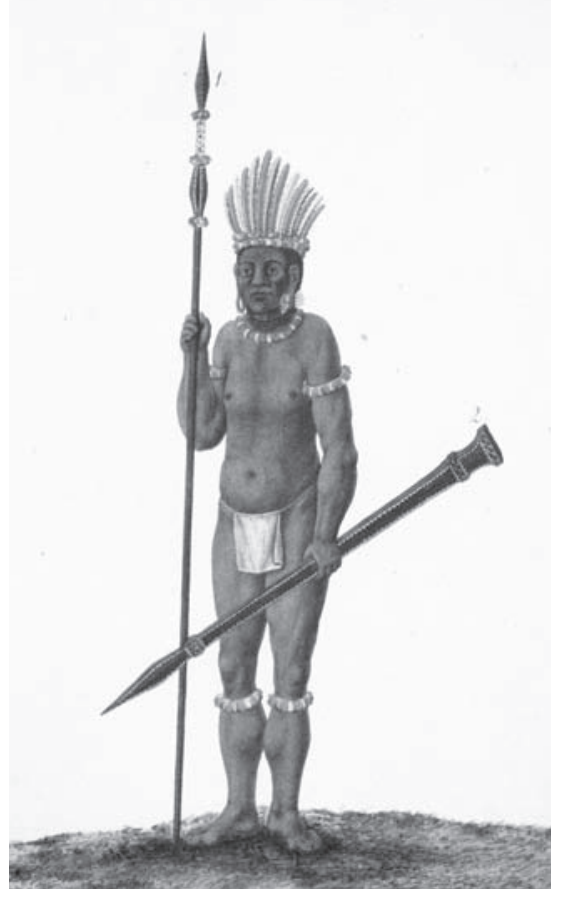

\section{Final comments}

This study considers the iconographic and documentary evidence in the context of paleopathological inquiry, contributing to our understanding of cultural practices and diseases affecting the Amazonian inhabitants during the late $18^{\text {th }}$ century. From either watercolors or documental/ethnographic materials collected by the naturalist Alexandre Rodrigues Ferreira and 
preserved in Brazilian and Portuguese institutions, we can learn about the procedures and knowledge behind different types of body modifications. Some of the cultural practices described can be identified on bones/skeletons while on the contrary, others, affecting soft tissues, will remain anonymous from the anthropological/bioarcheological record.

\section{Acknowledgments}

We would like to thank the $3^{\text {rd }}$ PAMinSA 2009 and Sheila Mendonça de Souza for her comments on our presentation.

\section{Bibliographic references}

Acuña, F. C. de. 1994. Novo descobrimento do grande Rio das Amazonas. Rio de Janeiro, AGIR.

Areia, M. L. R.; Miranda, M. A.; Hartmann, T. 1991. Memória da Amazónia: Alexandre Rodrigues Ferreira e a Viagem Philosophica pelas capitanias do Grão-Pará, Rio Negro, Mato Grosso e Cuyabá. 1783-1792. Coimbra, Museu e Laboratório Antropológico da Universidade de Coimbra.

Areia, M. L. R.; Miranda, M. A.; Martins, M. R. 2005. Alexandre Rodrigues Ferreira na Universidade de Coimbra. In: Ferrão, C.; Soares, J. P. M. (coord.). Viagem ao Brasil de Alexandre Rodrigues Ferreira: Colecção etnográfica. Lisboa, Kapa Editorial, Vol. II.

Aufderheide, A. C.; Rodríguez-Martín, C. 1998. The Cambridge encyclopedia of human Paleopathology. Cambridge, Cambridge University Press.

Buikstra, J.; Ubelaker, D. 1994. Standards for data collection from human skeletal remains: Proceedings of a seminar at the Field Museum of Natural History. Fayetteville, Arkansas, Arkansas Archeological Survey Research Series, n. 44.

Costa, M. F. 2001. Alexandre Rodrigues Ferreira e a capitania de Mato Grosso: imagens do interior. História, Ciências, Saúde - Manguinhos, 8 (suplemento): 993-1014.

Dasen, V. 1988. Dwarfism in Egypt and classical antiquity: iconography and medical history. Medical History, 32(3): 253-276.

Domingues, Â. 1992. Olhares sobre o Brasil nos séculos XVII e XVIII: os pintores Holandeses e Portugueses. In: Dias, J. R. (coord.). Nas vésperas do mundo Moderno: Brasil. Lisboa, Comissão Nacional para as Comemorações dos Descobrimentos Portugueses: 183-207. 
Fee, E.; Brown, T. M.; Lazarus, J.; Theerman, P. 2002. The effects of the corset. American Journal of Public Health, 92(7): 1085.

Feldman, W. H. 1965. Gerhard Henrik Armaeur Hansen: what did he see and when? International Journal of Leprosy, 33(3): 412-416.

Ferreira, A. R. 1788. Memória sobre os gentios Catauixis. [online]. [Consulted in 23-9-2010]. Available at: http://www.filologia.org.br/pereira/textos/memoria_sobre_os_gentios_catauixis.htm.

Ferreira, A. R. 1971. Viagem filosófica pelas capitanias do Grão Pará, Rio Negro, Mato Grosso e Cuiabá: 1783-1972: Iconografia. Rio de Janeiro, Conselho Federal da Cultura.

Ferreira, A. R. 1974. Viagem filosófica pelas capitanias do Grão Pará, Rio Negro, Mato Grosso e Cuiabá. Memórias: Antropologia. Rio de Janeiro, Conselho Federal de Cultura, Vol. I.

Ferreira, A. R. 2005a (1787). Memória sobre a figura que têm os Gentios Emauás. In: Soares, J. M.; Ferrão, C. (coord.). Viagem ao Brasil de Alexandre Rodrigues Ferreira. Colecção Etnográfica. Lisboa, Kapa Editorial, Vol. III: 32-33.

Ferreira, A. R. 2005b (1781). Memória sobre os Gentios Cambebas. In: Soares, J. M.; Ferrão, C. (coord.). Viagem ao Brasil de Alexandre Rodrigues Ferreira. Colecção Etnográfica. Lisboa, Kapa Editorial, Vol. III: 7-10.

Ferreira, A. R. 2005c (1787). Memória sobre os Gentios Iurupixunas. In: Soares, J. M.; Ferrão, C. (coord.). Viagem ao Brasil de Alexandre Rodrigues Ferreira. Colecção Etnográfica. Lisboa, Kapa Editorial, Vol. III: 30-31.

Ferreira, A. R. 2005d (1788). Miranhas. In: Soares, J. M.; Ferrão, C. (coord.). Viagem ao Brasil de Alexandre Rodrigues Ferreira. Colecção Etnográfica. Lisboa, Kapa Editorial, Vol. III: 34-35.

Ferreira, A. R. 2005e (1787). Gentios que habitaram e habitam nele, pela ordem dos rios indicados no tit. 15. ${ }^{\circ}$. In: Soares, J. M.; Ferrão, C. (coord.). Viagem ao Brasil de Alexandre Rodrigues Ferreira. Colecção Etnográfica. Lisboa, Kapa Editorial, Vol. III: 51-63.

Haworth, J. C.; Chudley, A. E. 2001. Dwarfs in art. Clinical Genetics, 59(2): 84-87.

Kozma, C. 2006. Dwarfs in ancient Egypt. American Journal of Medical Genetics, 140A(4): 303-311.

Larsen, C. S. 2002. Bioarchaeology: the lives and lifestyles of past people. Journal of Archaeological Research, 10(2): 119-166.

Leiker, D. L. 1989. Differential diagnosis. In: Hastings, R. C. (ed.). Leprosy. Edinburgh, Churchill Livingstone, Longman Group: 177-192.

Lima, A. P. 1953. O Doutor Alexandre Rodrigues Ferreira. Lisboa, Agência Geral do Ultramar, Divisão de Publicações e Biblioteca. 
Lima, A. P. 1954. As matrículas do Doutor Alexandre Rodrigues Ferreira. Boletim da Sociedade Broteriana, 18 (2. ${ }^{\mathrm{a}}$ série): 77-80.

Lovell, N. 2000. Paleopathology description and diagnosis. In: Katzenberg, M. A.; Saunders, S. (eds.). Biological anthropology of the human skeleton. New York, Wiley-Liss: 217-248.

Millington, G. W. M.; Levell, N. J. 2007. Vitiligo: the historical curse of depigmentation. International Journal of Dermatology, 46(9): 990-995.

Netto, L. 1882. As deformações da face e do craneo entre os povos americanos. Revista da Exposição Anthropologica Brazileira, 17-18.

Ortner, D. J. 2003. Identification of pathological conditions in human skeletal remains. Amsterdam, Academic Press.

Raminelli, R. 2001. Do conhecimento físico e moral dos povos: Iconografia e taxionomia na viagem Filosófica de Alexandre Rodrigues Ferreira. História, Ciências, Saúde - Manguinhos, 8 (suplemento): 969-992.

Ribeiro, B. G. 1988. Dicionário do artesanato indígena. Belo Horizonte, Editora da Universidade de São Paulo.

Roberts, C.; Manchester, K. 2005. The archaeology of disease. $3^{\text {rd }}$ edition. Gloucestershire, Sutton Publishing.

Rodrigues-Carvalho, C.; Souza, S. M. 1998. Uso de adornos labiais pelos construtores do Sambaqui de Cabeçuda, Santa Catarina, Brasil: uma hipótese baseada no perfil dento-patológico. Revista de Arqueologia, 11: 33-46.

Schnabel, T. G.; Schnabel, M. H. 1986. The dangers of dress: medical hazards in fashion and fads. Transactions of the American Clinical and Climatological Association, 97: 183-190.

Schwarz, G. S. 1979. Society, physicians, and the corset. Bulletin of the New York Academy of Medicine, 55(9): 551-590.

Simon, W. J. 1983. Scientific expeditions in the Portuguese overseas territories (1783-1808) and the role of Lisbon in the intellectual-scientific community of the late Eighteenth century. Lisboa, Instituto de Investigação Científica Tropical.

Souza, S. M. 2009. Personal communication during the discussion of the presentation made at the 3rd Paleopathology Association Meeting in South America, in Necochea, Argentina, 14th-16th October 2009.

Torres-Rouff, C. 2003. Oral implications of labret use: a case from Pre-Columbian Chile. International Journal of Osteoarchaeology, 13(4): 247-251.

Waldron, T. 2009. Palaeopathology. Cambridge, Cambridge University Press.

Wells, C. 1971. Ossos, corpos e doenças. Lisboa, Editorial Verbo.

Artigo recebido a 3 de Fevereiro de 2010 e aceite a 14 de Junho de 2010. 